\title{
地域在住高齢者を対象とした慣性センサを用いた歩行中の 膝不安定性評価モデルの構築
}

\author{
安在絵美 ${ }^{1,3}{ }^{\dagger}$, 浅野春菜 ${ }^{2}$, 中嶋香奈子 ${ }^{3}$, 児玉美幸 ${ }^{4}$, 小林吉 ${ }^{3}$, 才脇直樹 ${ }^{1,5}$, 太田 裕治 ${ }^{2}$ \\ ${ }^{1}$ 奈良女子大学, ${ }^{2}$ お茶の水女子大学, \\ ${ }^{3}$ 産業技術総合研究所人間拡張研究センター, ${ }^{4}$ 株式会社ピーベリー, ${ }^{5}$ 大阪大学
}

\begin{abstract}
要旨：膝の不安定性は変形性膝関節症の進行に関わるため歩行観察評価の着目点である. 本研究では地域でも利用可能な客観 的な膝不安定性評価のためのシステム構築を目指し, 歩行中の膝不安定性に関連する特徴量を明らかにすること, および観察 評価に対する推定モデルの構築を目的とした. 高齢者 70 名 (71.2 \pm 6.6 歳)を対象に, 歩行中の下肢の加速度と角速度を計測し, 不安定性については理学療法士の観察による 5 段階評価を実施した．結果より滕不安定性の増大には, 膝上左右加速度の増大, 膝上鉛直方向加速度の減少，膝下の進行方向軸周りの角速度増大が関連していた．交差検証にて作成されたモデルはいずれも 上記 3 つ指標を選択しており, 膝不安定性の評価に貢献する可能性が示された.
\end{abstract}

キーワード：滕の不安定性, 慣性センサ, 歩行評価, 順序ロジスティック回帰分析, 変形性膝関節症

\section{1. はじめに}

変形性膝関節症（Knee osteoarthritis, 以下, 膝 OA）の 罹患者数は世界で 2 億 5 千万人を超え, 国内外で最も一般 的な関節症の 1 つである ${ }^{1)}$. 膝 $\mathrm{OA}$ が進行すると, 加齢や 機械的ストレスなどの生体力学的変化により, 膝痛を伴い, 重度の場合では歩行困難となる. 膝 OA の診断はX 線検査 による医学的重症度診断と患者の主訴をもとに行われてお り, 症状が進行してから診断されるケースが多い. 一方で, 国内の大規模縦断的疫学調査によると膝 OA の推計罹患者 (2530 万人) のうち有症状有病者数は 780 万人と 3 割以下 であることから ${ }^{2)}$, 多くは無症状のまま発症, あるいは重症 化する対象者である，特に山間部や農村部では，都市部よ りも膝 OA の有病者数が多いことが報告されており ${ }^{3)}$, 医療 アクセスや専門家の不足などの課題も相まって, 潜在的に 重症化する対象者がより増大することが考えられる。これ に対して地方自治体では膝痛等を抱える対象者に健康運動 プログラムを提供しており, 地域での要介護化の予防に向 けた取組みが期待される. 効果的な介入を実施するために も, 地域の中で実用可能なリスク対象者の評価手法が求め られる。

膝 $\mathrm{OA}$ 特有の歩行時の特徵として, 膝の不安定性が挙げ られる ${ }^{4,5}$. 不安定性は 'giving way', ‘buckling’ あるいは

2021 年 1 月 22 日受付 2021 年 4 月 22 日受理

${ }^{\dagger}=630-8506$ 奈良県奈良市北魚屋西町

奈良女子大学生活環境部

安在 絵美

Tel: 0742-20-3532 ‘shifting’ などと表され, 歩行などの活動時に起こる膝の動 的な不安定性を示す ${ }^{7)}$. 急激かつ異常な荷重移動が伴うこと から, 6〜8 割の膝 OA 患者が症状を自覚していることが 明らかになっている ${ }^{6,7)}$. そして, この症状により膝痛増大, 転倒などの恐怖感を招くため, 身体活動制限に影響するこ とが報告されている ${ }^{8,9)}$. Fitzgerald ${ }^{6)}$ によって膝 OAに おける不安定性の自覚症状の発生数が明らかにされたこと をきっかけに，不安定性に関連する因子を明らかにするた めの研究が行われてきた. そして多くの研究で, 三次元動 作解析装置等を用いた運動学的解析を行い, 不安定性に関 する客観的な特徵を明らかにしてきた ${ }^{10)}$. このように歩行 中の不安定性は, 膝 OA の特有の症状として着目され, リ ハビリテーションや運動指導等の現場において重点的に取 り組まれる観察評価項目の一つとなっている.

理学療法ならびに運動指導等の現場において膝の不安定 性評価を行う際, 先行研究で用いられる三次元動作解析装 置が適用されることは非常に稀である. 実際にはこれらの 研究から明らかにされた評価ポイントに対して観察評価が 実施されることがほとんどである。このような主観的な観 察評価は臨床に導入しやすく, わかりやすい利点がある一 方, 験者間の見方の違いがある点や, 経験のある専門家が いないと評価が難しい点が課題である. 近年では加速度・ 角速度センサによる歩行評価が行われており ${ }^{11,12)}$, センサ 精度や臨床研究での簡便性は向上しているが, その結果の 解釈にも専門性を要するために導入しにくいといった課題 も挙げられる。 これに対して, 本研究で提案する手法は, 理学療法士等の専門家がすでに身に着けている観察評価方 法の暗黙知を定量化し，それらを予測する手法である。す なわち, センサによる客観的な予測が可能であれば, 対策 
手法が明確になるだけでなく, 前述したような行政が運営 する運動プログラム等の現場でも適用可能となり, 専門家 が少なく, 介入が行き届かない現場でも評価が可能になる ことが考えられる。

以上より, 本研究では, 歩行中の膝不安定性を客観的に 評価可能なシステムを目指し, (1)観察による膝不安定性を 客観的に定量化すること，そして(2)理学療法士の観察によ る歩行評価に対する(1)の定量データの推定モデルの開発を 目的とした，本研究では膝 OA の発症有無に関わらず膝の 不安定性が見られる方を対象とし, 地域の中で早期対策に 有用な評価システムを目指す。そのため地域在住高齢者を 対象に, 簡易に計測可能な加速度・角速度センサを用いた 計測を行い，それに基づく歩行評価モデルの構築を行う。

\section{2. 方法}

\section{1 慣性センサを用いた歩行計測システム}

本研究では, 歩行中の膝の動的な不安定性に着目するた め, 小型 9 軸計測センサ（TSND121, ATR-Promotions）を 用いた。 本センサは加速度センサ $( \pm 16 \mathrm{G})$ と角速度セン サ（土2000 dps）を搭載したセンサで, サイズは $46 \mathrm{~mm}(\mathrm{~W})$ $\times 37 \mathrm{~mm}(\mathrm{H}) \times 12 \mathrm{~mm}$ (D) である. Android 端末用のア プリケーションを開発し, Bluetooth 通信（Class2）にてデー 夕収集を行った（図 1)。センサの配置は, 下肢運動解析を 行う際に主として使用される足首・膝下 ・ 膝上の前面 3 箇 所とした (図 2). 先行研究において, 足首センサは初期接 地の検出に用いられ, 膝下と膝上のセンサは大腿と下腿の 動摇や関節角度の推定に用いられている ${ }^{11,13,14)}$. 従って本 研究でもこれらの手法を参考に設置個所を 3 点とした.

膝上, 膝下のセンサは, 立位姿勢の状態で脛骨の内外顆 点で結ばれる軸に対して各センサの ML (Medial and lateral) 軸が平行となるよう設置した，高さに関しては，固定の際に センサの縦幅より上下 $1 \mathrm{~cm}$ ずつ広い幅の伸縮ベルトを使用 しており, その伸縮べルトの上端と下端をそれぞれ滕蓋骨 の下端と上端位置に合わせた，足首の慣性センサも同様に， 内顆と外顆で結ばれる線を軸としてセンサの ML 軸を合わ せた．高さについては伸縮べルトの下端を内顆と外顆の上 端に固定した。

なお，本論文ではセンサの側方方向の軸を ML，前後方

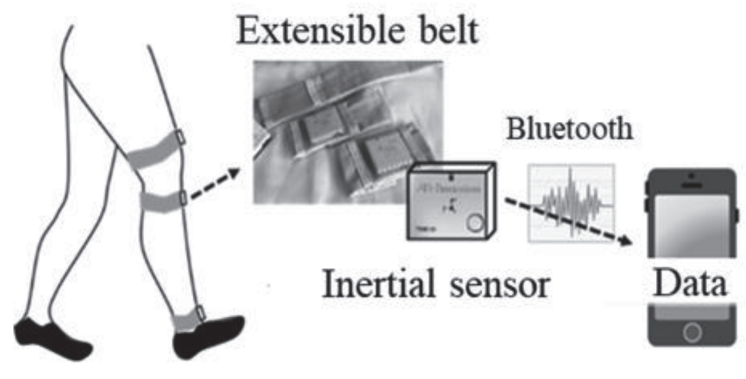

図 1 慣性センサを用いた歩行計測システム
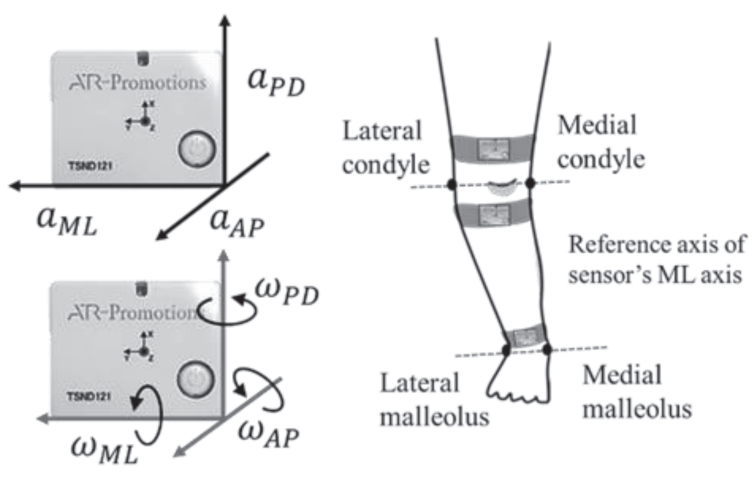

図 2 加速度 - 角速度方向と着用時の基準軸 $a$ : 加速度, $\omega$ : 角速度, ML : 側方方向 (Medial-lateral), AP : 前 後方向 (Anterior -posterior), PD : 上下方向 (Proximal-distal). 加 速度の AP 方向は進行方向に対して正, 角速度は軸の+方向に対し て時計回りを正とする。

向を AP (Anterior and posterior), 上下方向を PD (Proximal and distal）と表し，図 2 のように各軸の加速度をそれぞれ $a_{M L}, a_{A P}, a_{P D}$, 各軸周りの角速度をそれぞれ $\omega_{M L}, \omega_{A P}, \omega_{P D}$ と表記する. 慣性センサの設置位置と各軸の方向について も図2 に示した通りである. 加速度では, $\mathrm{AP}$ 軸は進行方向に, ML 軸は外側方向に, PD 軸は上向きに+となる. 角速度は 加速度軸の+万向に対して時計回り（右回り）を+とした. また, 歩行時の立脚期を同定するため, 先行研究で開発さ れた足底圧力センサを用いて同時計測できるようにした ${ }^{15}$. 足底圧センサは足底の 7 箇所に感圧導電ゴムを用いた圧力 センサが配置されて打り,このうち踵と趾部のセンサから 着地と離地を検出することとした。両計測システムはそれ ぞれの Bluetooth 通信を経由してデー夕収集されるため, 計 測の際，一時的に共通のトリガ信号を入力することで同期 できる設計にした。な押，サンプリング周波数は両計測器 ともに $100 \mathrm{~Hz}$ とした。

\section{2 高齢者の歩行計測実験}

実験には, 秋田県の農村地区 (大潟村, 潟上市, 五城目 町, 八郎潟町, 三種町）に在住する高齢者 70 名（男性 10 名, 女性 60 名, 平均年齢 $71.2 \pm 6.6$ 歳）が参加した. 対象者の うち膝 OA の診断を受けている者は 26 名含まれていた，実 駼対象者は, 健康運動指導士が行う運動教室に参加する者 で, 独立歩行が可能な高齢者とした，実験前に，対象者には， 質問紙を用いて年齢, 身長, 体重, 医師による膝 OA の診 断有無とその時期, 手術経験の有無, 膝痛経験の有無を確 認した。 その上で 6 か月以内に下肢のけがや手術経験のあ る者, 重度の心疾患, 脳血管疾患の後遺症ならびに認知症 をもつ対象者は除外された。 なお，本研究は以下の倫理審 查委員会の審査と承認を経て実施された（産業技術総合研 究所人間工学実験委員会第 71120030-A-20180223-001 号, 奈良女子大学研究倫理審查委員会第 19-09 号, 㧍茶の水女 子大学生物医学的研究倫理特別員会第 2016-24 号). 実験実 施に当たり，すべての対象者には口頭と文書にて説明を行 
い書面にて同意承諾を得た。

計測で使用する靴は, 足底圧力センサで検知する足底 接地等に影響しないよう底面がフラットな靴（快歩主義 L011，アサヒシューズ）で統一し，実験対象者に最適なサ イズを選定した。実験対象者は裸足の状態で靴を着用し, 靴内にはサイズに合わせた足底圧力センサ用インソールが 挿入された． 2.1 で述べた慣性センサは実験対象者の膝痛を 強く感じる側の脚 (膝痛症状のない場合は右脚) に設置され, 伸縮ベルトを用いて固定された。実験では, 快適速度にお ける $10 \mathrm{~m}$ 往復歩行計測を行い, 同時に正面・側面からの動 画撮影を行った。また，計測した 70 名のうち 7 名は半年間 の膝痛予防教室に通った後, 再度同条件で計測を行ってお り, 今回の解析対象に含めた。 そのため延べ 77 名を解析対 象とした。

\section{3 理学療法士による歩行評価}

2.2 で対象にした高齢者の歩行観察評価を実施した。評価 者は, 変形性膝関節症を含む運動器疾患の歩行評価の臨床 現場経験が 3 年以上の理学療法士 5 名 (男性 4 名, 女性 1 名, 平均年齢 $31.2 \pm 4.2$ 歳）とした. 5 名の評価者 $\mathrm{A} \sim \mathrm{E}$ の経 験年数を表 1 に示した.

先行研究における歩行時の膝の不安定性評価は, その有 無で観察評価する方法 ${ }^{16)}$ や対象者自身による不安定性の自 覚を 5 段階あるいは 6 段階で評価する手法 ${ }^{7,10)}$ が行われて いる. 本研究では理学療法士等の他者の観察者による不安 定性評価を実施するにあたり, 実際の運動指導や理学療法 の現場では不安定性の有無だけでなく介入による効果を見 るために段階的に評価するケースがある点などを考慮し， 5 段階に設定した観察者評価を実施した。

5 段階評価を実施するにあたり, 評価者には 0 〜 の段階 的な数值を付与してもらう設定とした。 その際, 評価 4 を 最も不安定性が大きい評価とし，基準とした。 また，評価 0 を「まったく不安定性が見られない」，2を「中程度の不安 定性あり」，1 および 3 を各中間の程度として定義した.

評価実験は, 予備実験と本実験で構成され, 次のように 実施された。まず，予備実験では評価 4 の基準を定めるた めの評価を実施した。理学療法士 1 名（臨床経験 7 年）お よび健康運動指導士 2 名（膝 OA を含む膝痛を有する高齢 者の運動指導経験 10 年以上）の協力を得て, これまでの現 場経験から「最も膝が不安定」と評価される者が含まれる かどうかを調査し, 3 名の評価が一致した評価 4 の対象者を 選出した. 次に, 本実験として, 開発した PC 上のアプリケー ションにより 2.2 の実験で撮影された前面および側面方向

表 1 各評価者の経験年数

\begin{tabular}{|l|c|c|c|c|c|c|}
\hline Examiner & A & B & C & D & E & $\begin{array}{c}\text { Average } \\
(\text { SD) }\end{array}$ \\
\hline $\begin{array}{l}\text { Years of experience } \\
\text { [years] }\end{array}$ & 5.5 & 9 & 16 & 10 & 3 & $8.7(5.0)$ \\
\hline
\end{tabular}

の動画をランダムに再生させ膝関節の動的不安定性につい て評価した。必要であれば繰返し再生が可能な環境に設定 した．評価者は，アプリケーションにて予備実験で選出され た評価 4 の動画を常に参照でき, それを基準として 0 〜 の 5 段階評価を行った。評価者による評価では, 77 名の動 画（7 名は介入前後の動画を含む）のうち, 評価 4 と定義さ れた動画を除いた 76 個を評価対象とした。 また, そのうち 10 個を二度提示させ, 信頼性を検証した。 なお, 予備実験 で評価 4 を選定した 3 名は本実験での評価者 5 名には含ま れない.

\section{4 データ処理}

2.2 で計測したデータを分析するため, 各慣性センサの 值を 4 次の Butterworth low-pass フィルタにかけ, ノイズ を除去した ${ }^{11)}$. カットオフ周波数は $10 \mathrm{~Hz}$ に設定した. 次 に, 歩行周期の開始点である一側下肢の初期接地（Initial contact: IC) と, 遊脚期の開始点である足部が床から離れた 点（Toe off: TO）を同定した. 本研究と同部位を検出に用 いている先行研究の手法 ${ }^{17,18)}$ を参考に, IC の検出に足首の 信号を使用し ${ }^{17)}$ ， TO の検出には足首を使用した ${ }^{18)}$. なお， 本手法にて同定された IC ・ TO の検出時刻について足底圧 カセンサと比較した結果, 検出時刻の差は, IC では $0.04 \pm$ 0.01 秒, TO では $0.01 \pm 0.01$ 秒となり, 足首の慣性センサ を用いた手法の妥当性を確認している. 解析では歩行が安 定しない歩行開始直後 2 歩と, 歩行終了直前 2 歩を除いた データを解析対象とした。

次に, 分割された 1 歩毎のデー夕に対し, 歩行周期時間, 立脚期時間, 遊脚期時間, 立脚期 - 遊脚期の足首 - 膝下 . 膝上の各 3 軸に対する加速度 ·角速度の最大振幅值を算出 し, 全 39 項目の変数にまとめた. 左脚に着用した場合は, ML 軸加速度と AP および PD 軸周りの角速度について反転 処理を行った. そして, 全 39 個の変数に対し, 検出された 歩行ステップのうち加速期や減速期を含まない歩行開始時 からの 8 歩分を抽出および平均化した。 そして, 平均を 0 , 分散を 1 とする標準化処理を行い, 解析に用いた。

\section{5 解析方法}

\section{(1) 観察評価結果の信頼性の検証}

まず，評価時に二度再生した動画の評価点について評価 者内信頼性を検証した. 評価の際, 5 段階の順序尺度に対 する一致度を評価するため, Cohenの重み付き $\kappa$ 係数を用 い, $\kappa$ 係数 0.6 以上を基準とした ${ }^{19)}$. 次に, 5 名の 76 個の 動画に対する評価点の一致度を検討するため Fleiss の $\kappa$ 係 数を算出し ${ }^{20)}$, 評価者間の精度を検討した。解析にはSPSS （ver.25，IBM）ならびに Rstudio を用いた.

\section{(2) 順序ロジスティック回帰分析によるモデル構築}

評価者内信頼性検証にて基準を満たした評価者の評価点 から, 中央值を算出した. そして, 中央值を真值とし, 順 序ロジステジック回帰分析による歩行評価の推定モデルを 
表 2 不安定性に対する順序ロジスティック回㷌分析の結果

\begin{tabular}{|c|c|c|c|c|c|c|c|c|c|}
\hline \multirow{2}{*}{ Variable } & & & \multirow{2}{*}{ Coef. } & \multirow{2}{*}{ SE } & \multirow{2}{*}{$X^{2}$} & \multirow{2}{*}{ OR } & \multicolumn{2}{|c|}{$95 \% \mathrm{CI}(\mathrm{OR})$} & \multirow{2}{*}{$p$ value } \\
\hline & & & & & & & Lower & Upper & \\
\hline \multicolumn{10}{|c|}{ [Acceleration $-a]$} \\
\hline \multirow[t]{2}{*}{ Stance } & Femur & $a_{P D}$ & -0.85 & 0.28 & 8.85 & 0.43 & 0.24 & 0.74 & $<.01$ \\
\hline & & $a_{M L}$ & 1.26 & 0.35 & 13.1 & 3.51 & 1.84 & 7.10 & $<.001$ \\
\hline \multicolumn{10}{|c|}{ [Angular velocity - $\omega$ ] } \\
\hline Stance & Tibia & $\omega_{A P}$ & 0.65 & 0.28 & 5.25 & 1.91 & 1.13 & 3.35 & 0.02 \\
\hline
\end{tabular}

Coef.: coefficient, SE : standard error, OR: odds ratio, CI: confidence interval

作成することとした．事前に，処理された全 39 項目のセ ンサ值より，回帰分析に投入する変数の選択を次の手順で 行った。まず，多重共線性を考慮し，Pearsonの相関係数 が 0.7 以上の変数同士のうち, 理学療法士に上る歩行評価 との Spearmenの順位相関係数が低い方を除外した. 次に, leave-one-subject-out 法によりモデル作成および交差検証を 行った.すなわち，1名分をテストデータとして除外した上 で，ステップワイズ法（変数増減法，追加掠よび除去基準： $p<0.05 ） に よ り$, 変数選択を行い, 選択された変数を用い て順序ロジスティック回帰分析を行った. 目的変数を理学 療法士による評価結果, 説明変数を選択された変数とした。 そして，構築したモデルを用いて，1名分のテストデー夕 に対する予測を行い，これを69回（69名分）繰り返した. 最後に, 真値と予測值の一致度について Cohen の重み付き $\kappa$ 係数を用いて検証した. 上記のうちモデル構築やテスト データの推定まではJMP13.0（SAS）を，重み付き $\kappa$ 係数 の算出は SPSS（ver.25, IBM）を用いた.

\section{3. 結果}

\section{1 歩行評価の信頼性の結果}

理学療法士 5 名（評価者 $\mathrm{A} \sim \mathrm{E}$ ）の歩行観察評価結果に ついて評価者内信頼性を検証した結果, 重み付き $\kappa$ 倸数は 評価者 $\mathrm{A}$ で 0.66 , 評価者 $\mathrm{B}$ で 0.93 , 評価者 $\mathrm{C}$ で 0.81 , 評 価者 $\mathrm{D}$ で 0.80 , 評価者 $\mathrm{E} て ゙ ~ 0.89$ であった. 結果より, 評 価者全員が先行研究で $\kappa$ 係数の目安として揭載されている 0.60 以上を上回っていることから， 5 名全員の評価結果を 用いることとした ${ }^{21)}$. 次に, 評価者間信頼性を検証した結果, 5 名の評価の一致度を示す $\kappa$ 係数は 0.50 であり, 中程度の 一致が示された。

\section{2 不安定性モデルに関連する指標}

評価者 5 名の中央値を求めたところ, 不安定性評価の各 グレードの割合は，全体の 76 個に対して評価 0 が $0.0 \%(0$ 個), 評価 1 が $23.7 \%$ (18 個), 評価 2 が $31.6 \%$ (24 個), 評価 3 が 35.5\%（27 個）, 評価 4 が 9.2\%（7 個）であった. 不安定性モデルに対する変数選択に扔いて, 变数同士の
表 3 不安定性評価グレードに対する混同行列

\begin{tabular}{|c|c|c|c|c|c|c|c|}
\hline & \multicolumn{5}{|c|}{ Predicted grade } & \\
\hline & & 0 & 1 & 2 & 3 & 4 & \\
\hline \multirow{5}{*}{ 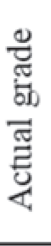 } & \multirow{5}{*}{$\begin{array}{l}1 \\
2 \\
3 \\
4\end{array}$} & 0 & 0 & 0 & 0 & 0 & 0 \\
\hline & & 0 & 9 & 4 & 5 & 0 & 18 \\
\hline & & 0 & 7 & 7 & 10 & 0 & 24 \\
\hline & & 0 & 4 & 7 & 16 & 0 & 27 \\
\hline & & 0 & 0 & 0 & 4 & 3 & 7 \\
\hline & & 0 & 20 & 18 & 35 & 3 & 76 \\
\hline
\end{tabular}

多重共線性を検討した結果，歩行周期時間，立脚期時間， 遊脚期時間, 立脚期の足首 $a_{P D}$, 足首 $a_{M L}$, 滕下 $a_{P D}$, 滕下 $a_{M L}$, 遊脚期の足首 $a_{M L}$, 膝下 $a_{A P}$, 膝下 $a_{P D}$, 滕上 $a_{P D}$, 足 首 $\omega_{M L}$, が除外された。 そして残った 27 個の変数を用いて leave-one-subject-out 法にて 69 回の順序ロジスティック回帰 分析を実施した結果，69 個すべてのモデルで共通して 3 個 の変数が選択された．表 2 に不安定性に対するこれら 3 つ の予測因子と順序ロジスティック回帰分析の結果を示した. モデルの偏回㷌係数は 3 つの変数すべてで $p<0.05$ の有意 性が示された。 なお，表 2 の代表モデルは, 76 個全体のデー タで構築した結果を示しているが, leave-one-subject-out 法 で作成された 69 個すべてのモデルにおいても同様に, 各変 数で $p<0.05$ の有意性が認められた。 69 個のモデルにおけ 了偏回帰係数の平均 $\pm \mathrm{SD}$ は立脚期・膝上 $a_{M L}$ で $1.26 \pm 0.04$, 立脚期 ・膝上 $a_{P D}$ で $-0.85 \pm 0.03$, 立脚期・膝下 $\omega_{A P}$ で 0.65 \pm 0.03 が示された. オッズ比は 1 より大きい時, 説明変数 の増加が不安定性に関与し, オッズ比が 1 より小さい時, 説明変数の減少が不安定性に関与することを示している. 表 2 より偏回帰係数の影響度とオッズ比を確認したところ， 順に, 立脚期 - 膝上 $a_{M L}\left(x^{2}=13.1\right.$, オッズ比 $(\mathrm{OR})=3.51, p<$ $0.001)$, 立脚期 - 膝上 $a_{P D}\left(x^{2}=8.85, \mathrm{OR}=0.43, p<0.01\right)$, 立 脚期・膝下 $\omega_{A P}\left(x^{2}=5.25, \mathrm{OR}=1.91, p=0.02\right)$ が影響度の強 い係数として不安定性との関与が明らかとなった。

\section{3 不安定性評価モデルの精度検証結果}

Leave-one-subject-out 法を用いて 69 個の予測モデルを構 
築し, 各テストデータに対する評価值が予測された。不安 定性 0 と評価された動画がなかったため, 推定モデルでは, 不安定性 1 - 4 の範囲で推定された. 評価者の中央值を真 值とし, 推定モデルによる予測結果との一致度を検証した. 表 3 に混同行列の結果を示した。 推定モデルによる予測評 価と真值との一致度として, $\kappa$ 係数は $0.47(p<0.001)$ であっ た. 予測された評価值は, 全体の 76 個に対して評価 1 が $26.3 \%$ (20 個), 評価 2 が $23.7 \%$ (18 個), 評価 3 が 46.1\%(35 個), 評価 4 が 3.9\%（3 個）となった. 真值に対して予測結 果が隣の評価值と混同するケースも多かった.

\section{4. 考察}

本研究では, 膝 OA の歩行観察評価で着目される膝関節 の動的不安定性に対し, 慣性センサを用いた客観的情報に 基づく評価モデルの構築を行った。ステップワイズ法によ る変数選択と順序ロジスティック回帰分析により, 不安定 性に関連するパラメータが明らかになった。

構築した不安定性評価モデルにおいて, その係数の影響 度とオッズ比の結果より, 不安定性の増大に伴い, 立脚期 膝上 $a_{P D}$ 減少, 膝上 $a_{M L}$ 増大が顕著であった (表 2). 先行 研究では滕の不安定性が見られる対象者の歩行の特徵とし て, 側方方向および前後方向の加速度増大が見られること が報告されている ${ }^{14)}$. さらに, 荷重応答期の急激な膝の動 摇は重症度に関連することも明らかにされている ${ }^{22)}$. した がって本研究の結果についても, 不安定性の増大に伴い, 荷重時の膝上 $a_{M L}$ 増大やそれを回避するための膝上 $a_{P D}$ 減少 として現れたと推察される. 加えて, 不安定性の増大に伴 い立脚期膝下 $\omega_{A P}$ 増大が関与していた。 これは特に, 歩行 の進行方向に対して外転の角速度が増大しており, 不安定 性による滕の外側への急激な変位とそれによる膝下外転の 動きが大きくなったことが考えられ, 先行研究の見解と一 致していた ${ }^{23)}$. 表 2 に示したモデルは 76 個すべての評価対 象から構築されているが, leave-one-subject-out 法により構 築した 69 個のモデルにおいても同様に立脚期膝上 $a_{P D}$, 膝 上 $a_{M L}$, 膝下 $\omega_{A P}$ が共通して選択された. 69 個のモデルでは 3 つ以外の因子が選択されることもなく, これらの予測因子 が膝の不安定性評価に寄与することが確認できた。

各モデルにより予測された評価值と評価者中央值との一 致度は, $\kappa=0.47$ であり先行研究 ${ }^{24)}$ における $\kappa$ 係数の基準 を参照すると中程度の一致であった. 今回の結果は決して 高くはなく，この要因として次の 3 点のことが考えられた. 1 点目として, 評価 0-4 の対象の割合が偏っていたことや その割合の低い評価グループ内の対象者数が少なかったこ とがモデルの学習精度に影響している可能性がある。特に, 評価 0,4 は評価 2,3 と比べてケースが少なく, 予測され た評価も 2,3 に集中している傾向が見られた.ロジスティッ ク回帰モデルの説明変数の数に対するデー夕数が十分では ないと考えられる ${ }^{25)}$. 不安定性の評価 0 がなかったことは,
評価の対象者が膝痛予防運動教室に通う高齢者であったこ とが要因と考えられる. また, 不安定性が評価 $1 \cdot 2$ となっ た動画数に対して評価 4 となった動画が少なかったことは, 実験対象者の条件を, “独立歩行が可能で, 自力で運動教室 まで来ることが可能な高齢者”としたため, 重症者が少な かったと考えられる. 特に, 本実験を実施した市町村の運 動プログラムでは評価 4 の対象者を多数集めるのは難しい ことが多い. そのため, モデルの対象範囲を拡大するため にも, 今後臨床での実験として継続し, これらの対象を増 やしていく必要がある. 2 点目として, 計測では下肢に着目 しているが理学療法士の評価では全身に対する下肢の運動 なども観察していることから, 下肢の運動のみでは捉えき れない点がある。実験に使用した計測システムでは, 歩行 中にセンサの座標系がグローバル座標系に対し常時変化し ており, 本システムのみでは, 実際のセンサの方向を判断 することが難しい. 例えば膝の不安定性においては, 左右 方向加速度の増加が, 膝関節の動きに起因するのか, 体幹 全体の体重移動に起因するのかを正確に区別することが困 難である，センサ数を増やしたり，歩行フェーズ分けやほ かのセンサとの関連によって対応付ける必要がある. 最後 に3 点目として, 5 名の評価者の評価の一致度としては中程 度の一致が示され, 各評価者の評価と中央值の一致度も $\kappa$ 係数 0.6 以上が確認されていることから，5名の中央值を用 いたモデル構築を行ったが, 隣合う評価值を採用する評価 者も見られている点も留意したい. 実験では, 不安定性の 主観的評価の手法を参考に 5 段階評価を行ったが, グレー ド化のための歩行評価ポイントが経験によって異なること が影響した可能性がある。また，本実験では動画を用いた 評価として環境を統一しているが, 実際の臨床現場では患 者が実際に歩行している様子を観察して評価を行う点にお いて環境の違いも課題となった. 今回の分析では全対象者 に対する全評価值をモデル構築に用いたが, 例えば評価の 自信度などを含めて代表值を定めることでより効果的なモ デルの学習につながることが考えられる. 一方, 今回の 5 名の結果は評価者内の再現性において妥当な結果が得られ ていることや，モデルに採用された変数はすべてのモデル で共通していたことなどから, 膝の不安定性評価に寄与す る予測因子やその影響度などの知見は, 今後のモデル構築 においても貢献できると考えられる.

実験に関する課題や今後の対策が挙げられる一方, 本研 究で開発したシステムは臨床現場でも用いやすく安価であ るため, より幅広い対象者や多数の人に適用できるという 利点がある. 特に, 滕の不安定性は膝 $\mathrm{OA}$ の重症度に関連 することが言われる一方で, 診断と治療が行われる患者は 一部であり, 多くが地域に潜在している, あるいは自覚し ながらも対処できていないケースも多い. そのため, 病院 以外でも評価と対策ができる仕組みが求められており, 行 政が提供する介護予防プログラムにおいても大きな課題と なっている. 本研究により, 専門家の観察評価に基づくモ 
デルが応用できれば, 地域現場での幅広い対象への評価が 行われ，それに基づく対策が明確となることが期待できる. 加えて, 臨床経験が浅い評価者に対する教育システムとし ても応用可能である。また，膝の動摇は膝 OA の重症度を 分別するための指標にもなっていることから ${ }^{22)}$, 将来的に 重症度推定が可能となる可能性も考えられた. 今後, 対象 者数の増大等の課題解決を進めることで, 専門家が不足す る現場でも歩行評価の一助となり, 地域在住高齢者に対す る効果的な運動指導等への貢献が期待される.

\section{5. おわりに}

本研究では, 歩行評価で着目される歩行中の膝の動的不 安定性について, 加速度 ·角速度センサを用いた評価推定 モデルの構築を行った。 その結果, 次の知見が得られた.

I . ステップワイズ法と順序ロジスティック分析を実施 し, 膝の不安定性の増大には立脚期の膝上側方方向 の加速度の増大, 膝上上下方向の加速度の減少, 膝 下進行方向軸周りの角速度増大が寄与していること が明らかとなった。

II . Leave-one-subject-out 法による複数のモデル構築およ び交差検証を行った結果, すべてのモデルにおいて 上記 I に挙げた予測因子が含まれたことから，これ らの因子が不安定性評価へ貢献することが確認され た。

III . 構築された評価モデルでの予測評価の一致率は $\kappa=$ 0.47 と中程度の一致が示されたが, 今後, 評価モデ ルの精度向上のためには, 不安定性の高い対象者を 増やし, 偏りを改善させる必要がある.

IV 。慣性センサを用いた計測は農村地区に住む高齢者が 集まる運動プログラムの中で適用でき, 現場での計 測システムの実用可能性が確認できた.

以上より, 人員不足などにより理学療法士による介入が 行き届かない様々な地域の現場においても定量的な歩行評 価が可能なことが示唆され, 効果的な運動指導ならびに地 域在住高齢者の運動機能把握への貢献が期待される.

\section{謝 辞}

本研究の一部は, JSPS 科研費 (若手研究 $18 \mathrm{~K} 18363$, 16K16478）の研究助成を受けて実施されました。 また，本 研究を遂行するにあたってご協力を頂きました株式会社 ピーベリー健康運動指導士 加藤光葉先生, 秋田県大潟村, 潟上市, 五城目町, 八郎潟町, 三種町の各市町村役場の皆 様に深く感謝いたします。

\section{参考文献}

1) Lopez, A. D., Murray, C. J. L. et al.: Years lived with disability (YLDs) for 1160 sequelae of 289 diseases and injuries 1990-2010: A systematic analysis for the global burden of disease study 2010, Lancet, 380(9859), 21632196, (2012).

2) Yoshimura, N., Muraki, S., Oka, H., Mabuchi, A., EnYo, Y., Yoshida, M., Saika, A., Yoshida, H., Suzuki, T., Yamamoto, S., Ishibashi, H., Kawaguchi, H., Nakamura, K. and Akune, T.: Prevalence of knee osteoarthritis, lumbar spondylosis, and osteoporosis in Japanese men and women: the research on osteoarthritis/osteoporosis against disability study, Journal of Bone and Mineral Metabolism, 27(5), 620-628, (2009).

3) Kang, X., Fransen, M., Zhang, Y., Li, H., Ke, Y., Lu, M., Su, S., Song, X., Guo, Y., Chen, J., Niu, J., Felson, D. and Lin, J.: The high prevalence of knee osteoarthritis in a rural Chinese population: the wuchuan osteoarthritis study, Arthritis \& Rheumatology, 61(5), 641-647, (2009).

4) Astephen, J. L., Deluzio, K. J., Caldwell, G. E. and Dunbar, M. J.: Biomechanical changes at the hip, knee, and ankle joints during gait are associated with knee osteoarthritis severity, Journal of Orthopaedic Research, 26(3), 332-341, (2008).

5) 大森豪：骨関節疾患リハビリテーションの実学（運動 器の 10 年) - 変形性膝関節症のリハビリテーション実 学 - 内側型変形性膝関節症の発症危険因子, 日本リ八 ビリテーション医学会, 45(2), 85-89, (2008).

6) Fitzgerald, G. K., Piva, S. R. and Irrgang, J. J.: Reports of joint instability in knee osteoarthritis: Its prevalence and relationship to physical function, Arthritis Care \& Research, 51(6), 941-946, (2004).

7) Wallace, D. T., Riches, P. E. and Picard, F.: The assessment of instability in the osteoarthritic knee, EFORT Open Reviews, 4(3), 70-76, (2019).

8) Felson, D. T., Niu, J., McClennan, C., Sack, B., Aliabadi, P., Hunter, D. J., Guermazi, A. and Englund, M.: Knee buckling: prevalence, risk factors, and associated limitations in function, Annals of Internal Medicine, 147(8), 534-540, (2007).

9) Knoop, J., Van Der Leeden, M., Van Der Esch, M., Thorstensson, C., Gerritsen, M., Gerritsen, M., Voorneman, R., Lems, W. F., Roorda, L. D., Dekker, J. and Steultjens, M. P.: Association of lower muscle strength with self-reported knee instability in osteoarthritis of the knee: Results from the Amsterdam osteoarthritis cohort, Arthritis Care \& Research, 64(1), 38-45, (2012).

10) Van Der Esch, M., Knoop, J., Van Der Leeden, M., 
Voorneman, R., Gerritsen, M., Reiding, D., Romviel, S., Knol, D. L., Lems, W. F., Dekker, J. and Roorda, L. D.: Self-reported knee instability and activity limitations in patients with knee osteoarthritis: Results of the Amsterdam osteoarthritis cohort, Clinical Rheumatology, 31(10), 15051510, (2012).

11) Kobsar, D., Osis, S. T., Boyd, J. E., Hettinga, B. A. and Ferber, R.: Wearable sensors to predict improvement following an exercise intervention in patients with knee osteoarthritis, Journal of NeuroEngineering and Rehabilitation, 14(1), 94, (2017).

12) Staab, W., Hottowitz, R., Sohns, C., Sohns, J. M., Gilbert, F., Menke, J., Niklas, A. and Lotz, J.: Accelerometer and gyroscope based gait analysis using spectral analysis of patients with osteoarthritis of the knee, The Journal of Physical Therapy Science, 26(7), 997-1002, (2014).

13) Rueterbories, J., Spaich, E. G., Larsen, B. and Andersen, O. K.: Methods for gait event detection and analysis in ambulatory systems, Medical Engineering \& Physics, 32(6), 545-552, (2010).

14) Turcot, K., Aissaoui, R., Boivin, K., Pelletier, M., Hagemeister, N. and de Guise, J. A.: The responsiveness of three-dimensional knee accelerations used as an estimation of knee instability and loading transmission during gait in osteoarthritis patient' s follow-up, Osteoarthritis and Cartilage, 17(2), 213-219, (2009).

15) Anzai, E., Tripette, J., Nakajima, K. and Ohta, Y.: Comparative study between a novel 7-sensor plantar pressure measurement insole and the F-scan device, IEEE 2nd Global Confidence on Life Sciences and Technologies, 339-342, (2020).

16) Sharma, L., Chang, A. H., Jackson, R. D., Nevitt, M., Moisio, K. C., Hochberg, M., Eaton, C., Kwoh, C. K., Almagor, O., Cauley, J. and Chmiel, J. S.: Varus thrust and incident and progressive knee osteoarthritis, Arthritis \& Rheumatology, 69(11), 2136-2143, (2017).

17）西野一郎, 緒方公介, 野見山宏, 安永雅克, 西嶋幸司, 藤原明, 山田昌登嗣：歩行解析における加速度計の有 用性，整形外科と災害外科，42(3)，1038-1040，(1993).
18) Tong, K. and Granat, M. H.: A practical gait analysis system using gyroscopes, Medical Engineering \& Physics, 21(2), 87-94, (1999).

19) Cohen, J. A.: Coefficient of agreement for nominal scales, Educational and Psychological Measurement, 20(1), 37-46, (1960).

20) Fleiss, J. L.: Measuring nominal scale agreement among many raters, Psychological Bulletin, 76(5), 378-82, (1971).

21) Landis, J. R. and Koch, G. G.: The measurement of observer agreement for categorical data, Biometrics, 33(1), 159-174, (1977).

22) Chang, A., Hayes, K., Dunlop, D., Hurwitz, D., Song, J., Cahue, S., Genge, R. and Sharma, L.: Thrust during ambulation and the progression of knee osteoarthritis, Arthritis \& Rheumatology, 50(12), 3897-3903, (2004).

23) Chang, A. H., Chmiel, J. S., Moisio, K. C., Almagor, O., Zhang, Y., Cahue, S. and Sharma, L.: Varus thrust and knee frontal plane dynamic motion in persons with knee osteoarthritis, Osteoarthritis and Cartilage, 21(11), 16681673, (2013).

24) Viera, A. J. and Garrett, J. M.: Understanding interobserver agreement: the kappa statistic, Family Medicine, 37(5), 360-363, (2005).

25) Peduzzi, P., Concato, J., Feinstein, A. R. and Holford, T. R.: Importance of events per independent variable in proportional hazards regression analysis II, Journal of Clinical Epidemiology, 48(12), 1503-1510, (1995).

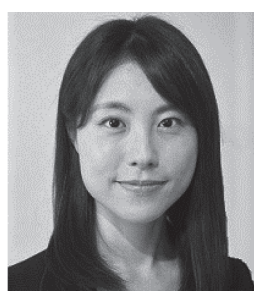

安在絵美（あんざいえみ）

2017 年お茶の水女子大学大学院人間創成 科学研究科ライフサイエンス専攻博士後 期課程修了. 同年日本学術振興会特別研 究員 (PD), 産業技術総合研究所特別研 究員を経て 2019 年 4 月奈良女子大学生 活環境学部特任講師, 現在に至る. 高齢者福祉工学, 生体計測, 歩行分析研究に従事. 


\title{
Knee Instability Assessment Model During Walking for Community-Dwelling Older Adults Using Inertial Sensors
}

\author{
Emi ANZAI ${ }^{\dagger \dagger}$, Haruna ASANO ${ }^{2}$, Kanako NAKAJIMA ${ }^{3}$, Miyuki KODAMA ${ }^{4}$, Yoshiyuki KOBAYASHI ${ }^{3}$, \\ Naoki SAIWAKI1 $1^{5}$, Yuji OHTA ${ }^{2}$ \\ ${ }^{1}$ Faculty of Human Life and Environment, Nara Women's University, ${ }^{2}$ Ochanomizu University, \\ ${ }^{3}$ Human Augmentation Research Center, National Institute of Advanced Industrial Science and Technology, \\ ${ }^{4}$ Peaberry corporation, ${ }^{5}$ Osaka University
}

\begin{abstract}
This study aimed to create models of knee instability using inertial sensors. Seventy older adults, aged $71.2 \pm 6.6$ years, participated in this study. The acceleration and angular velocity were obtained using inertial sensors placed on the lower limb and five physical therapists assessed the knee instability of the subjects hierarchically. Thirty-nine variables, including the amplitudes of the acceleration, and the angular velocity for each sensor and for the three axes, were extracted. Multivariate ordered logistic regression analysis was performed to identify the factors affecting knee instability in the observational assessment. And the five-graded knee instability assessment models were created using variables that were excluded if they correlated with each other. The results indicated that the increased lateral acceleration [odds ratio $(\mathrm{OR})=3.51, \mathrm{p}<0.01$ ] and the decreased vertical acceleration $[\mathrm{OR}=0.43$, $\mathrm{p}<0.01$ ] of the distal femur in the stance phase, and the increased angular velocity of the proximal tibia in the stance phase $[\mathrm{OR}=1.91$, $\mathrm{p}<0.01]$ were significant predictive factors for knee instability. This study found that all of the above three indicators were selected in all models driven by stepwise selection in each leave-one-subject-out cross-validation. Therefore, these factors could be used for knee instability evaluation model.
\end{abstract}

Key Words: Knee instability, Inertial sensor, Walking assessment, Ordered logistic regression analysis, Knee osteoarthritis

Received Jan. 22, $2021 \quad$ Accepted Apr. 22, 2021

${ }^{\dagger}$ Emi ANZAI

Faculty of Human Life and Environment, Nara Women's University, Kitauoya-Nishimachi, Nara City, 630-8506, JAPAN,

Tel: 0742-20-3532 